\author{
Federico Ruozzi \\ (Bologna)
}

\title{
CATHOLIC CHURCH AND THE ITALIAN PUBLIC TELEVISION. AN ENDURING RELATION WITH AN INTERLUDE: THE COUNCIL
}

\begin{abstract}
The article presents the entanglement of the Catholic Church and the media by focusing on the case of the Second Vatican Council and the television broadcast of its events. The mass media attention of the council stimulated, according to the author, a double level: the media conveyed more information about the church event than it had ever done before, but at the same time, the mass media influenced the discussion of the council fathers. The article also analyzes, through the lens of the Council, the recent relationship between the Catholic Church and the Italian television.
\end{abstract}

\section{Key words}

Second Vatican Council, Italian Public Television, Pope, TV Series 
"A Council deliberates documents. But not only. A Council makes history".

Karl Lehmann

In the 1920s, the Holy See forbade the participation at the mass by means of radio frequency. Nowadays, more than 5 million people in Italy follow the rite on TV screens, broadcast by two channels: one public and statecontrolled (Raiuno) and one private (Berlusconi's Retequattro). Ironically, the religious channel, TV2000, owned by the Italian Episcopal conference, begun to broadcast the mass some years after its establishment ${ }^{1}$.

The last decades have shown how the religious dimension is strictly linked to the electronic media; one should mention the examples of televangelists in the U.S. or Al Jazeera in the Arab world. As a matter of fact, all the religions have been exploiting the media system: Pentecostalists, Buddhists, Jews, Hindus and many other religious movements more often promote their activities through audio-visual messages ${ }^{2}$. As a "New York Times" article underlined some years ago, "religion finds technology".

What about the Catholic Church? During his long pontificate (1978-2005), Pope John Paul II paid more attention than his predecessors to the media, especially to their use as a pastoral means. Wojtyła emphasized the relevant role of modern communications in the encyclical Redemptoris missio (December $7^{\text {th }}, 1990$ ) on the permanent validity of the Church's missionary mandate:

The first Areopagus of the modern age is the world of communications, which is unifying humanity and turning it into what is known as a "global village". The means of social communication have become so important as to be for many the chief means of information and education, of guidance and inspiration in their behavior as individuals, families and within society at large. In particular, the younger generation is growing up in a world conditioned by the mass media. To some degree perhaps this Areopagus has been neglected. Generally, preference has been given to other means of preaching the Gospel and of Christian education, while the mass media are

\footnotetext{
${ }^{1}$ The Vatican Television Centre, under the directorship of by D.E. Viganò, has collaborated also with Sky TV for some papal media-events, during the pontificate of pope Francis.

${ }^{2}$ B. Meyer, A. Moors (eds.), Religion, Media, and the Public Sphere, Bloomington 2006; N. Echchaibi, From audio tapes to video blogs: The delocalisation of authority, Islam, Nations and Nationalism 17, 1, 2011, pp. 25-44; H.A. Campbell (ed.), Digital religion: Understanding religious practice in new media worlds, Abingdon-New York 2013.

${ }^{3}$ See: New York Times, May $16^{\text {th }}, 2002$. See also the dramatic use of the new media by religious terrorism: C. Uva, Il terrore corre sul video, Soveria Mannelli 2008; P. Seib, D.M. Janbek, Global Terrorism and New Media, London-New York 2010.
} 
left to the initiative of individuals or small groups and enter into pastoral planning only in a secondary way ${ }^{4}$.

Because of this personal positive attitude towards the media, especially towards television, Wojtyła has monopolized the study on the media and the Catholic Church; it should not be forgotten that he personally founded the Vatican Television Centre in $1983^{5}$. In fact, many sociologists, semioticians and scholars studying the media launched a new field of study dedicated to the Pope and the contemporary media system 6 .

However, it must not be forgotten either that the Italian public television broadcast its first official transmissions under Pius XII's pontificate, in January $3^{\text {rd }}, 1954$, anticipated by an apostolic exhortation on the television ${ }^{7}$, while the first Pope to be seen on screen was Leo XIII in 1896, only one year after the first official film show by the Lumière brothers ${ }^{8}$. Thus, there is a very interesting and long-standing relationship between the Catholic Church and the audio-visual media, dating back the $19^{\text {th }}$ century, which so far has been only marginally studied.

Question then arise regarding the religious function of television and its influence on the Catholic Church: is it only a new and powerful means of evangelization, or is it something more? Which representation has been spread by the Italian public television in their broadcasts of religious events? How has the image of Church changed in the $20^{\text {th }}$ century? It goes without saying that televised material can be used now as a precious source for the historian in order to answer all these questions: "As «the age of television» itself ends, the time is ripe for us to study the medium in a serious historical manner", as Graham Roberts observed in the preface to "The Historian, Television and Television History":

\footnotetext{
${ }^{4}$ John Paul II, Ecyclical Redemptoris missio, December $7^{\text {th }} 1990$ [online]. Vatican [access: 2015-05-30]. Available at: <http//w2.vatican.va/content/john-paul-ii/encylics/documents/hf_jp-iienc_07121990_redemptoris-missio.html $>$.

${ }^{5}$ For its history, see: D.E. Viganò (ed.), Telecamere su San Pietro. I trent'anni del Centro Televisivo Vaticano, Milano 2013.

${ }^{6}$ See for instance the pages dedicated to John Paul II by D. Dayan, E. Katz, Media Events. The Live broadcasting of History, Cambridge, Mass. 1992; G. Mazza (ed.), Karol Wojtyła, un pontefice in diretta. Sfida e incanto nel rapporto tra Giovanni Paolo II e la tv, Roma 2006; F. Boni, Il corpo mediale del leader, Roma 2002.

${ }^{7}$ Pius XII, Exhortation on television, January 1, 1954, Acta Apostolicae Sedis 46, 1954.

${ }^{8}$ R. Eugeni, D.E. Viganò (eds.), Attraverso lo schermo. Cinema e cultura cattolica in Italia, 1-3, Roma 2006.

${ }^{9}$ G. Roberts, The Historian and Television: a methodological survey, [in:] G. Roberts, P.M. Taylor (eds.), The Historian, Television and Television History, Kent 2001.
} 
Whatever can be said for the future of television, its past has not been served well by historians. Despite being the prevalent medium for information and entertainment in most advanced countries since the 1960s, there remain remarkably few serious works of history that embrace television as a primary source of information for those years ${ }^{10}$.

This essay aims at exploring the complex collaboration between the Italian Catholic Church and the media by focusing on a salient example such as the Second Vatican Council (1962-1965), which left an indelible and unique mark on the Church history, the public sphere and the Italian media.

\section{THE SECOND VATICAN COUNCIL: THE GREATEST ASSEMBLY EVER. ITS HISTORY}

Before analysing the relationship between the Second Vatican Council and its representation conveyed via television, I would like to briefly outline the context of this religious event, whose $50^{\text {th }}$ anniversary of conclusion (December $\left.8^{\text {th }}, 1965\right)^{11}$ is to be celebrated this very year by the Catholic Church.

The Second Vatican Council was held in Rome from October $11^{\text {th }}, 1962$ to December $8^{\text {th }}$, 1965; Pope John XXIII instituted it with the aim of renewing the Catholic Church and bringing it up to date with modern times (see the Italian term aggiornamento). Just three months after his election as a successor of Pius XII (January 25 $5^{\text {th }}$ 1959) Pope John XXIII announced his decision to convene a Council. The so-called Vatican II started 3 years later and Pope Paul VI continued it after John's death in June 1963. The announcement of the Council was unexpected for all the bishops, all the cardinals and for the Holy See in general. Cardinals elected Pope Roncalli, hoping for a transitional pontificate: he was 77 years old! The Roman curia wanted a peaceful and quiet papacy after the second world war and the "reign" of Pope Pacelli.

\footnotetext{
${ }^{10}$ Ibidem, p. 174.

${ }^{11}$ For a historical reconstruction of this event, see the five volumes edited by G. Alberigo and J.A. Komonchak (for the English edition), History of Vatican II, Maryknoll-Leuven 1995-2006. As Alberigo wrote in his preface "1965-1995: Thirty years after Vatican II": “Thirty years after the close of the conciliar assembly that took place in Rome between 1962 and 1965, it is worth asking ourselves what is the present state of knowledge of this Council, the way it unfolded, and its meaning" (ibidem, XI). For a history of this History, see: A. Melloni, F. Ruozzi, Vatican II and the History of Vatican II, [in:] S.G. Kochuthara (ed.), Revisiting Vatican II: 50 Years of Renewal, I, Keynote and Plenary Papers of the DVK International Conference on Vatican II, 31 January-3 February 2013, Bangalore 2014, pp. 102-118, and the issue dedicated to 1962-2012: la storia dopo la Storia? Contributi e prospettive degli studi sul Vaticano II dieci anni dopo la Storia del concilio, Cristianesimo nella storia 31,2013 , edited by S. Scatena.
} 
Thus, Roncalli "seemed the most suitable and prudent solution"12. He proved otherwise. He did leave his mark on Church history; in fact the Second Vatican Council has generated considerable debate, mainly on its interpretation and its reception (as Faggioli writes: "The truly «ecumenical» impact of Vatican II makes the reception of the council even more complex") ${ }^{13}$, as all the important synods in the Christian history had done ${ }^{14}$. It definitively closed the Tridentine Era, opening a throroughly new one ${ }^{15}$.

For the first time in its history, 3000 Fathers gathered in Rome to discuss the Catholic Church and its relationship with modern society. Patriarchs, cardinals, bishops, and general superiors of the religious orders came from each and every Catholic corner of the world (from Africa, China, Asia), and even from countries beyond the Iron Curtain. It was an enormous event. Italian journalists, cameras and the people of Rome, for example, anxiously waited for the arrival of the train carrying Card. Stefan Wyszyński, Archbishop of Warsaw, and the Polish bishops (among whom there was the young auxiliary Bishop of Cracow, Karol Wojtyła) at the Termini station in Rome. Observers of the Oriental, Protestant and Anglican Churches came as well, together with a number of Orthodox Church observers. Countries of Asia and Africa were also well represented, for the first time in Church History. As the Jesuit John O'Malley wrote:

The vague purposes announced for the Council thus evoked a wide range of expectations, hopes, and fears in the three and one-half years between the Pope's announcement of his decision and Vatican council II's beginning ${ }^{16}$.

When the Council started there was no clear indication of what direction it would take and which side (the Roman Curia, the future majority or minority of the Council, the Pope) would dominate.

\footnotetext{
${ }^{12}$ See: G. Alberigo, Papa Giovanni (1881-1963), Bologna 2000 and A. Melloni, Papa Giovanni. Un cristiano e il suo concilio, Torino 2009.

${ }^{13}$ M. Faggioli, Vatican II: The Battle for Meaning, New York-Mahwah-NJ 2012, p. 1.

${ }^{14}$ See: Breve guida ai giudizi sul Vaticano II, [in:] A. Melloni, G. Ruggieri (eds.), Chi ha paura del Vaticano II?, Roma 2009, pp. 107-14; The research on the Vatican II was monitored by M. Faggioli in the review Cristianesimo nella storia. See: M. Faggioli, Concilio Vaticano II: bollettino bibliografico, Cristianesimo nella Storia 24, 2003, pp. 335-360, on the years 2000-2002; 26, 2005 , pp. 743-767, on the years 2002-2005; 29, 2008, pp. 567-610, on the years 2005-2007; 31, 2010, pp. 755-791, on the years 2007-2010; 34, 2013, pp. 927-956, on the years 2010-2013.

${ }^{15}$ See: P. Prodi, Il paradigma tridentino, Brescia 2010.

${ }^{16}$ J. O'Malley, Tradition and Transition. Historical perspectives on Vatican II, Wilmington 1988, p. 12.
} 
In fact, Latin American, Asian, and African bishops were initially hardly able to take part in the debate which was held in Latin, the official language of the Church at that time. Although assumed to be a uniform language, it was actually diversified because of the different accents, pronunciations and inflections. Despite centuries of passive non-responsibility, active participation of the bishops signalled a profound change. The entire assembly of bishops became the soul of the Council. Shortly, the fathers began to become aware of themselves and of their role: they did not always accept the first drafts put forward by the Roman bishops, thus opening new discussions. First of all, the assembly debated all the preliminary works carried out by the Roman Curia, breaking its secular hegemony: “The assembly", as O'Malley wrote, "encouraged an examination of all aspects of ecclesiastical life and thus gave the Council an open-ended agenda"17, accepting a proposal of renewal which had been opposed for many years and confronting the profound problems of the Church and contemporary society. For the first time in the Christian history, the largest assembly had been gathered in the same place in order to discuss the future of the Church itself.

Indeed, as many journals reported, "the first and most visible characteristic of Vatican II was the large number of participants" 18 , as the images broadcast by Italian television demonstrated to the world.

\section{THE SECOND VATICAN COUNCIL AND THE MEDIA}

For the first time in history, a council was convoked in the Media Age, and, for the first time, its images were broadcast all over the world ${ }^{19}$. Its importance

provided the press, the radio and the new media of television with a notto-be-missed event of change within an institution, the Catholic Church, which had always held immutability as a strength ${ }^{20}$.

In fact, Italian public television (RAI) played a key role in the reception of this religious event. It must be kept in mind that the second Vatican Council

\footnotetext{
${ }^{17}$ Ibidem, p. 13.

${ }^{18}$ H. Raguer, An initial profile of the assembly, [in:] G. Alberigo, J.A. Komonchak, History of Vatican II, II, p. 169.

${ }^{19}$ S.M. Hoover, Religion in the Media Age, London-New York 2006; C. Deacy, E. Arweck (eds.), Exploring religion and the sacred in a media age, Farnham 2009.

${ }^{20}$ M. Faggioli, Vatican II: The Battle for Meaning, p. 6.
} 
was only the second important media event for the Italian television, after the Olympic Games held in Rome in 1960, and the first religious media event in general. Rai was under the close control of the Christian party: this control was so strong as to call its general director Ettore Bernabei with the nickname "the cardinal", in view of his relations with the Christian Democracy and the Vatican. On one hand, he was the trusty man of the politician Amintore Fanfani, who was the Prime Minister during those years, while on the other, the Substitute of the Secretariat of State, Angelo Dell'Acqua, would receive him at weekly audiences for updates on the progress of the TV project.

As a matter of fact, "the interest and expectations by the announcement of January, 1959, led the press and other mass media to undertake to keep public opinion informed"21. As already mentioned, the Council marked an important turning point in the relationships between the media and the Church itself. In fact, for the first time, the Church realized that it was impossible to communicate only through its private media, such as the journal "L'Osservatore Romano" and the Vatican Radio. In particular, John XXIII announced his intention to inform the journalists immediately about the counciliar works. Again, for the first time in the Vatican history, an Office press was created with the task of giving the journals, the reviews, the televisions and the radios in Rome a daily report. Following the conclusion of the Council, the Press Office, was turned into the actual well-known Press Room of the Holy See. This was a crucial stage in Catholic history: the First Vatican council, summoned in 1869 , for example, was entirely secret and there are few traces of the events in the papers, most of which focus on the gossip from the Curia ${ }^{22}$.

Despite some initial difficulties in breaking the secular tradition of ecclesiastical secret, after 1963 the news about the Council began to circulate freely, under the pressure of the contemporary media system as well as Catholic media (especially the influential Italian newspaper "L'Avvenire d'Italia", headed by Raniero La Valle).

Moreover, the Second Vatican Council was also the first council to debate and pass a decree about the media (Inter mirifica, December 1963, approved with the highest number of non placet), recognizing their relevant role in the

${ }^{21}$ J. Oscar Beozzo, The external climate, [in:] G. Alberigo, J. Komonchak (eds.), History of Vatican I, I, pp. 357-404.

${ }^{22}$ L. Veuillot, Rome pendant le concile, 1-2, Paris 1872; C. Ceccuti, Il concilio Vaticano I nella stampa italiana (1869-1870), Roma 1970. 
contemporary society ${ }^{23}$. In those circumstances, it is evident that newspapers, radio and television offered a bulk of information, never seen and experienced during any previous Council.

\section{THE TELEVISION CAMERAS AND THE COUNCIL}

Due to the importance of television for the Vatican II, televised images and news are precious research tools for the historian (alongside traditional documents such as Acta et documenta, Acta Synodalia, the documents stored in the Vatican Secret Archive and those found in local or private ones: diaries, letters etc. $)^{24}$.

Why are television sources so important? Because Italian public television in particular provided a worldwide coverage of this event. This medium had the privilege and the control of the representation of the Council all over the world since it was exclusively responsible for all the broadcasts relating to the event. Indeed, an agreement with the Vatican was concluded. As the director of the most important Italian religious journal at that time wrote:

The Italian television would be the only one to have free admittance in the Vatican and the coverage of every Papal event, but in exchange for this, the images had to be broadcast all over the world ${ }^{25}$.

Rai directly covered the entire event, supplying all the material to foreign televisions and radios, so the European television networks were able to show the Council live. For these reasons, Italian television made an effort in terms of equipment, journalists and technicians. They turned Saint Peter basilica into a kind of a large studio, with lights and electric systems offered by Philips, microphones, broadcasting stations, overcoming the natural audio and visibility problems that characterized the First Vatican Council, in 1869-

${ }^{23}$ See E. Baragli, Inter Mirifica, Roma 1969; the issue dedicated to the document in Centro Vaticano II - CVII, Studi e ricerche VIII, 2014, p. 1; F.-J. Eilers, Inter mirifica in Asia, Concilium 1, 2014, pp. 133-134 and J. Palakeel, Inter mirifica. The Pledge of a New Era in Church and Social Communication, [in:] S.G. Kochuthara (ed.), Revisiting Vatican II 50 years of Renewal, I, pp. 551-566.

${ }^{24}$ For an in-depth analysis, see: F. Ruozzi, Il concilio in diretta. Il Vaticano II e la televisione tra informazione e partecipazione, Bologna 2012. See also: idem, India and Indian Catholicism on Italian television. The Italian television programmes about the Second Vatican Council as an opportunity to explore the local Churches away from Rome, [in:] S.G. Kochuthara (ed.), Revisiting Vatican II: 50 Years of Renewal, II, Selected Papers of the DVK International Conference on Vatican II, 31 January-3 February 2013, Bangalore 2015, pp. 29-52.

${ }^{25}$ Raniero La Valle, L'opinione pubblica e Giovanni XXIII: Essere giornalisti, Cristianesimo nella Storia 25, 2004, pp. 579-580. 
-1870. The electricity that illuminated the basilica would be sufficient to power the entire Vatican State for one year. The live broadcasting of history showed to the world the celebrations, and the most importantly General Congregations of the counciliar fathers in Saint Peter's Basilica.

One striking example is the opening ceremony of the Second Vatican Council, on October $11^{\text {th }}, 1962$. It ushered in the era of the worldwide transmission and its international broadcasting was made possible by Telstar, the first communication satellite launched on July $10^{\text {th }}, 1962$, broadcasting the Council simultaneously to 18 international press agencies connected via Eurovision network. The material televised by the Italian broadcaster was used by 66 televisions. The airing of the opening ceremony - from 8.30 am to $1.00 \mathrm{pm}$ on the Italian first channel - was Europe's longest live television report of that time. But not only: thanks to Telstar, the papal blessing at 13.30 pm was the first worldwide television connection between Europe and North-America showing such a great event after the experimental tests:

It was a most impressive sight, enabling even the most distant observers to get an idea of what was happening and eliciting strong reaction. The festive hope of the beginning became an image the whole world could see ${ }^{26}$.

Therefore, the role of television in recording the historical and visual memory of this event has no precedent in history. More specifically, not only did the Italian television follow this religious event when the council started, in October 1962, but also during the preparation phase (from 1960 to 1962). It continued to follow the Council until the 1965, going against all the logic and rules of media events ${ }^{27}$. Since the Vatican Council was a media event that lasted for three years, it was the longest media events ever.

In particular, it used different ways to explain the Council to the public opinion, employing many television genres: weekly programmes, news, documentaries for children, documentaries on the history of the Church and the Councils, historical programmes in general, interviews with theologians, historians, and experts on ecumenism and liturgy. For example, during the preparation stage and the First Session of the Council (from September 1962 to December 1962), Rai would inform the public opinion with news reports, with live comments and direct coverage, as well as with special services and historical programmes, not only for adult audience but also for children. As

${ }^{26}$ A. Riccardi, The Tumultuous Opening Days of the Council, [in:] G. Alberigo, J.A. Komonchak (eds.), History of Vatican II, II, p. 10.

${ }^{27}$ See: D. Dayan, E. Katz, Media Events. 
previously mentioned, Italian television did develop a program addressed specially to children; this underlines the lengths to which Italian television went to communicate the event to every type of audience.

Thus, for the historian, the Italian public television service, due to its extensive coverage of the Council, is an extremely important analytical tool. In order to follow the Council, Rai TV decided to rely on experts of theology (periti) and history of the Church and Councils, such as the scholars working at the Bologna Institute for Religious Studies founded by Giuseppe Dossetti in the $1950 \mathrm{~s}^{28}$. For example, Giuseppe Alberigo, one of the foremost experts on the Second Vatican Council, the chief editor of the famous "History of Vatican II" translated into seven languages, was also the author of two historical series devoted to the history of the Council and the analysis of the first session for Channel Two. The programmes produced were important because through the voices of the historians, bishops, Christian observers, and theologians, showed the Italian viewers the theological and ecclesiological debate inside the Catholic Church and taught the history of the Councils, unknown by most; some Italian faithful, interviewed by the public television in the summer 1962, confused, for example, the last Council (1869) with the last crusade.

An important element which cannot be underestimated is the airing time of these TV programmes: most of these historical transmissions were broadcast after the television news, in prime time, at $9 \mathrm{pm}^{29}$. On their television screens, Italian televiewers could watch the most important transalpine theologians discussing the problems of Catholicism, condemned by the Holy Office of Pope Pius XII some years before, and now totally reinstated under John's pontificate, right after the general news.

As already observed, it was an important opportunity for Italian Catholics to acquire some knowledge in areas such as ecumenism, critical reading and analysis of the Bible, the role of the bishops or Liturgical Renewal Movements; gain direct insight into cultural, social or religious situation of the countries where the bishops came from (poverty, interreligious dialogue, religious freedom, peace and war); learn about the characteristics of Christianity in other countries (such as Germany, France, the Netherlands or

\footnotetext{
${ }^{28}$ A. Melloni (ed.), Giuseppe Dossetti (1913-1996). Studies on an Italian Catholic Reformer, Bologna Lectures 2006, Münster 2008.

${ }^{29} 1962$ The year of the Council was broadcast on Channel Two on September $7^{\text {th }}, 14^{\text {th }}$ and $21^{\text {st }}$, 1962 , at $9.05 \mathrm{pm}$. The church and the Council was broadcast in November $\left(10^{\text {th }}, 24^{\text {th }}\right)$ and December $\left(8^{\text {th }}, 22^{\text {nd }}\right)$ at $10.15 \mathrm{pm}$.
} 
United States or countries of the East), or about local churches (especially in Latin America, Africa, Asia) which were totally ignored by Italians due to their religious laziness and the traditional closeness of the Holy See and the Roman Curia, which monopolized and centralized the debate.

In conclusion, recent history has shown how the Council was layered with a variegated body of sources: not only approved texts and theological minutes and treatises, but also, for example, private papers, letters, diaries and, not least of all, images. Indeed, the Council iconography (from Council icons to frescoes, prints and engravings) is a type of document in which the appropriate questioning of the elements gathered might be useful for a full understanding of the event. It can definitely be said that the photographs from the $19^{\text {th }}$-century Vatican I and audio-visual imagery of the $20^{\text {th }}$-century Vatican II stand as the natural evolution of that iconography, now preserved in museums and churches all over the world, like the Menologion of Basil II describing Nicaea II, or the frescos or etchings depicting Trent. It can therefore be said that the television coverage from the years of the Council left an indelible mark on the history of television, but it was also an important factor for a deeper, multifaceted understanding of Vatican II.

The reorganization of the RAI archives (undertaken by RAI Teche), the archiving and digitization of its broadcasts, extended to include the Luce historical archive (an audiovisual archive founded in the Twenties), the new management of the Vatican film library, an initial inventory and transfer of all audiotapes at the Vatican Secret Archives, now make the material available for consultation and study. Documentation produced by television has always been underestimated by historians, and relegated to studies of mass media $^{30}$, but it appears as a source for this event in particular, and for the history of the Church and of the Popes in the $20^{\text {th }}$ and $21^{\text {st }}$ century in general. Due to their specific nature, as it will be shown, these documents also became players in the event itself.

${ }^{30}$ See G. Roberts, P.M. Taylor (eds.), The Historian, Television and Television History, Luton 2001; C. Delporte, L. Gervereau, D. Maréchal (eds.), Quelle est la place des images en histoire?, Paris 2008. 


\section{TELEVISION AT THE COUNCIL: THE WINDOW AND THE ACTOR OF THE EVENT}

What do the audiovisual images show us? As already mentioned, the public could listen to the different voices and opinions within the Christian community, because for the first time, Italian television allowed the bishops to speak to the world through their interviews. But for the first time the television also showed a global Church, that was once invisible to the society of the $1960 \mathrm{~s}^{31}$. Italian public could thus see the image of the universal Catholic Church: the African, Latin American, Asian bishops together with the North American and European bishops. Television was then a window that looked onto a world unknown to and precluded from the vast majority of the televiewers; a world that through television images of the different colours of the mitres and the white mantles, of the black and violet paraments and of the golden crowns of the Eastern prelates, showed all the differences of a Church that John XXIII wanted to be just one. Unconsciously, RAI achieved a revolution: until then television had shown just single fragments of the Pope's public life or his Pastoral activities. The image of the cardinals, bishops, priests, theologians, Orthodox and Protestant delegates, or simply faithful Christians from around the world departed from the Pope's visual monopoly. Actually, Italian television had always focused its attention on him, forgetting that the Catholic Church is not only the Pope.

Italian television was also the first medium that revealed the changes decided by the Council: for example, it showed the new form of the mass which would no longer be held in Latin, and the important role of the parishioners. The images broadcast by TV gave a real and original form to the liturgical reform.

Television was not only a window on this event; given the ontological nature of the televisual images ${ }^{32}$, it was also an actor of the event since no other previous Council had ever been so widespread, getting in through the Saint Peter's door. Television turned out to be a real player in the Council story, and on different levels.

${ }^{31}$ J. Bignell, A. Fickers (eds.), A European Television History, New York 2009; A. Fickers, C. Johnson (eds.), Transnational Television History. A Comparative Approach, London-New York 2012.

${ }^{32}$ See A. Grasso (ed.), Fare storia con la televisione. L'immagine come fonte, come evento, come memoria, Milano 2006. 
On one level, it was about how television directly impacted the Council event, playing a major role, and there are clues to this in the diaries written by the Council Fathers or theologians (peritus, in Latin of the Curia): the role of TV was to make up for the real participation in the celebrations. Many just watched the ceremonies on TV instead of attending in person. The Lovanian theologian Moeller, for example, watched the ceremony on TV; Cardinal Giacomo Lercaro, Archbishop of Bologna (Italy), in a letter sent the same evening to his community, did not describe the grandeur and the solemnity of the ceremony ${ }^{33}$, because he assumed that it had been "watched on TV"34. Even Neophytos Edelby, a young bishop of the small Melkite Church, adviser and secretary to Patriarch Maximos IV Saigh, realized that the Italian television was offering a service and in the pages of his diary he noted that the patriarch, unable to participate in the "solemn and moving" ceremony, was nevertheless able to watch it all thanks to television. Again, the French theologian Yves Congar noted in his diary that:

Father de la Brosse, who watched the entire ceremony on TV (until 12.30), tells me that it was all lovely and that the filming and commentary were excellent. And, with Telstar (the satellite) the whole world was able to see it all, at the very moment it was taking place.

On a second level, an instance of the TV as an active actor of the Council is offered by the programme La Chiesa a concilio (October-December 1962) in which the constitutionalist Costantino Mortati filled the gaps in the conciliar rules on the documents rejected by the assembly. The opinions he expressed on TV screen in prime time broke the impasse between bishops' different interpretations of the Ordo concilii. Subsequently, when Pope Paul VI delivered his speech on peace at the conference of the United Nations in New York (October, $\left.4^{\text {th }} 1965\right)$, the fathers followed it directly, thanks to its live broadcast. Then, the conciliar discussion against the war was modelled on the Pope's words. Father Congar promptly wrote in his diary:

At 2.15 pm we saw the Pope's arrival in New York (2:27 pm): live on TV. So we were witnesses of the very moment in which the event occurred. Fantastic ${ }^{35}$.

\footnotetext{
33 “TV sul Concilio. Papa Giovanni stanco, preoccupato e grave. La bontà gli si legge in viso. Lo spirito di grazia profonda, autentica (?) in tutta la sua persona. La breve parte orientale della cerimonia incarna l'ecumenicità della Chiesa. Ma non ci si può nascondere che le strutture sono proprio latinamente latine". Cfr. il diario di Ch. Moeller, 11 ottobre 1962 (Fscire Archive, Bologna).

${ }^{34}$ G. Lercaro, Lettere dal concilio 1962-1965, G. Battelli (ed.), Bologna 1980, p. 62.

${ }^{35}$ Y. Congar, Diario del concilio, II, Cinisello Balsamo 2005, p. 351 (October $\left.4^{\text {th }} 1965\right)$; orig. ed.: Paris 2002.
} 
If the information conveyed by the "small screen" acted as an effective agent within the Council ( $a b$ intra), this was even truer for the outside world ( $a b$ extra). As a matter of fact, the public opinion was informed through the press, the radio, and also through the television of what the Catholic Church was doing; the Council Fathers had to act accordingly, taking into consideration the public opinion formulated by an attentive and well-informed audience: these viewers were not simply passive spectators of the show, "but through the news media also acted as a sounding board, with undeniable results"36.

The impact of television or radio information on the Council debate, and on how the public perceived it, can be observed in a discussion that took place in February 1965, in the De religionibus not christianis group. Congar noted in the pages of his private diary dated February $26^{\text {th }}, 1965$ :

Willebrans explain that the Arabs of the Middle East (we have their vivid reactions to hand) were irritated by the Arabic propaganda broadcast by Israeli radio, which they listen to a lot. And that radio repeated like a refrain that the Council has recognized the innocence of the Jews ${ }^{37}$.

Then, on September $15^{\text {th }}, 1965$, he noted:

The Pope also wanted the Muslim world to be better informed not only on this issue but in general on the work of the Council. We tried to give correct information and explain things on the radio, to gather some influential experts who would have a positive effect on the public opinion ${ }^{38}$.

Thus, the mass media attention on this event created an unexpected relationship of centripetal and centrifugal forces: from an internal to external perspective, the media (radio, paper, but above all, television) conveyed more information about the conciliar events and about what happened inside than had ever been done before; from an external to an internal perspective, mass media influenced the Council fathers themselves, orienting their discussion.

\footnotetext{
${ }^{36}$ Ibidem, p. 168.

${ }^{37}$ Ibidem, II, p. 281 (February $\left.26^{\text {th }} 1965\right)$.

${ }^{38}$ Ibidem, II, p. 329 (September $\left.15^{\text {th }} 1965\right)$. See also: March $1^{\text {st }} 1965$.
} 


\section{ITALIAN TELEVISION AS A COLLECTIVE DIARY OF CATHOLICISM}

For the way it appeared and for what it offered, television can be compared to sources such as memoirs. Thus, it is somehow the equivalent of the personal diaries written by the Council Fathers during their stay in Rome ${ }^{39}$.

The television source, then similar to Fathers' Council diaries and private memoirs, offers the reader/viewer a story that adds colour to those moments, making them take form and softening any stiffness. And just like the private diaries written for Vatican II, the television source also distances itself from a merely assertive function, which characterized, for example, the diaries of the Council of Trent. Like all these sources, even if it presents just a partial, subjective, biased, incomplete, or abundant view - and in any case controlled by the narrator, who is not singular but becomes plural in this case, it is still essential "to make the history of the Council as a Council"40.

One key difference distinguishes the nature of these sources. While the private papers reveal the point of view of the individual (cleric, expert, observer, layman), the "television of the Council" (as we can call the Italian television project relating to the Council conceived by Rai TV) can be seen as a large collective "council diary", a useful and unpublished „memoir of the entire assembly" in a broad sense. It is simultaneously a pro memoria sua diary, a Council leader's diary, a theologian's diary, a layman's diary, a journalist's and an observer's diary ${ }^{41}$. The polyphony of the voices of interviewees allows the researcher who wants to listen to grasp the Council's overall dimension, not to mention the climate of that experience of communion and the assessment of the developing opinio communis. Additionally, this collective diary contains significant misgivings, mediations and contradictions and, at the same time, it also follows the inherent logic of television (time factor, compression, simplification, synthesis, schedule) and of the audio-visual image itself (with its signs and codes: framing, edits, cuts, direction), adding further interpretations.

The importance and novelty of the space and the pulpit that television granted to the Council can also be observed - as already mentioned - in the

\footnotetext{
${ }^{39}$ Cfr. M.-D. Chenu, Notes quotidiennes au Concile, A. Melloni (ed.), Paris 1995; L. Kenis, Diaries. Private Sources for a Study of the Second Vatican Council, [in:] D. Donnelly, J. Famerée, M. Lamberights, K. Schelkens (eds.), The Belgian Contribution to the Second Vatican Council, Leuven 2008, pp. 29-54.

${ }^{40}$ Ibidem, p. 13 (see the Italian version: Bologna 1996).

${ }^{41}$ Ibidem.
} 
fact that the people interviewed wrote down in their diaries the frequent requests for interviews, not only made by the Italian television, but above all by foreign broadcasting companies. Willebrands, Lercaro, Câmara, Tucci, Semmelroth, Schillebeeckx, Congar, Schutz are just some of the examples ${ }^{42}$.

Congar gave so many interviews and was a guest on so many TV shows that when he happened to take a taxi on November $21^{\text {st }}, 1962$, to go to the RAI studios for a Sunday programme with several observers, it was not until he arrived that he realized he had made a mistake, confusing the dates of his several appointments ${ }^{43}$.

In particular, these cases show how the Council television was not just a window - if I may be allowed the expression - onto that great assembly, that promise - as Grasso and Scaglioni wrote - typical of information broadcasts $^{44}$, but also a real player, an agent of history, able to intervene actively in the very event ${ }^{45}$.

The decisive role that television played in the Council is therefore clear: not just as an information box but as a medium operating on different levels of participation and perception.

\section{WHAT IS THE IMAGE OF THE CATHOLIC CHURCH NOW ON TV: FROM JOHN PAUL II TO POPE FRANCIS AND THE CASE OF RELIGIOUS TV SERIES}

The image of the Church that this event showed on television was totally new. The construction of the Church image after the birth of Italian television can be divided in two different phases, where the Council represented a new and important interlude. In general, before the Council, all the media were inclined to underline the "ornamental or sentimental dimension of religion, often in contrast with the modernity or in an ideological way" ${ }^{46}$,

\footnotetext{
${ }^{42}$ See for example, J. Willebrands, Les agendas conciliares de mgr J. Willebrands, trans. L. Declerck, Leuven 2009; G. Lercaro, Lettere dal concílio; H. Camara, Vaticano II: Correspondêcia conciliar. Circulares á família do São Joaquim, L.C. Marques (ed.), Obras completas: 1/1 1962-1964, Recife 2004; R. Tucci, Diario del concilio (Archivio Fscire); O. Semmelroth, Diario del concilio (Archivio Fscire); Y. Congar, Mon Journal du Concile, Paris 2002 and K. Schelkens, The Council Notes of Edward Schillebeeckx 1962-1963, Leuven 2011.

${ }^{43}$ Y. Congar, Diario del concilio, I, p. 257 (November, 21 ${ }^{\text {st }}$ 1962). Cfr. ibidem, p. 260 (November $25^{\text {th }} 1962$ ).

${ }^{44}$ A. Grasso, M. Scaglioni, Che cos'è la televisione, Milano 2003, p. 95.

${ }^{45}$ P. Sorlin, L'immagine e l'evento. L'uso storico delle fonti audiovisive, Torino 1999.

${ }^{46}$ See: G. Ambrosio, Quale immagine della chiesa attraverso i media? Le linee di fondo, [in:] La Chiesa e i media, Milano 1996, p. 151.
} 
following the stereotypical image of traditional and popular culture. After the Second Vatican, on the one hand, media have paid more attention to the religious dimension, and, on the other hand, the Church has opened itself to the contemporary media society, using it more consciously.

However, if, during the three years of the Council, Italian television showed the Catholic Church in its universality, with its problems, its hopes, its natural different opinions, then after this event Italian television has concentrated again on the image of the Pope, dimming the collegiate church status, the ecumenical dimension, and the different voices inside the Catholic world ${ }^{47}$. Diachronically, we can see that the television program schedule has shifted its focus back exclusively to the Pope, to the grand solemn events (such as the funeral of the Pope, the conclave and the Pope's election, the Jubilee or the festive celebrations), or to few charismatic figures (such as certain promoters of religious movements), completely neglecting the religious, theological and ecclesiological analysis.

As anticipated in the introduction, the visual monopoly of the Pope was emphasized in particular during the past decades, due to the great charisma of Pope John Paul II. He used all the media and his personal presence to spread the evangelical message, through his pilgrimages, his body, his physicality, his suffering, carrying out a genuine communicative revolution, for a Pope. Now the media have pointed their cameras at Pope Francis. He is more prepared to face the journalists, more spontaneous and instinctive than his predecessor pope Benedict XVI. An analyst as Henri Tincq wrote that "Jorge Mario Bergoglio a révolutionné la manière de communiquer des papes" ${ }^{\prime \prime}$, that is, he has revolutionized the ways Popes communicate. Nevertheless, if John Paul II and Francis are similar because they have both embraced the media, the approach of these two popes is really different. It is impossible not to perceive how the journalists and the televisions exploited the disease of John Paul II, taking advantage of his personality and fame. On the other hand, Pope Francis gives the impression of being able to use the media and not be used by them, rejecting any kind of exploitation and manipulation:

Depicting the pope as a sort of Superman, a star, is offensive to me. Mythologizing and idealizing him, he said, is a kind of "aggression" (...).

\footnotetext{
${ }^{47}$ See: F. Ruozzi,Voci e immagini della fede: radio e tv, [in:] A. Melloni (ed.), Cristiani d'Italia 1861-2011. Chiese, Società, Stato, I, Roma 2011, pp. 471-486.

${ }^{48} \mathrm{H}$. Tincq, Le pape François est devenu le roi de la com' [online]. Slate France [access : 2014-03-12]. Available at: <http://www.slate.fr/story/84459/pape-francois-communication-twitter $>$.
} 
The pope is a man who laughs, cries, sleeps calmly and has friends like everyone else. A normal person.

- he said in an interview for the Italian newspaper "Corriere della Sera".

Another interesting case-study that show the recent relationship between Italian TV and Catholic Church is represented by the beatification ceremony of Mother Teresa of Calcutta in St. Peter Square on October 19 ${ }^{\text {th }}, 2003$ : that religious event was also a great media event, broadcast by 77 television channels from 48 different countries. Over $40 \%$ of Italian televiewers watched the liturgical ceremony on TV. It had a large share and a great audience. It was the most popular religious broadcast of the year. This celebration exemplifies the typical behaviour of Italian television with respect to religious events, defined by a mixture of holy and profane or secular elements ${ }^{49}$. These holy rites were a driving force for a TV feature about Mother Teresa, broadcast in the evening by the same channel with 11 million televiewers (Madre Teresa, directed by Fabrizio Costa, 176'). In fact, the real ceremony was accompanied by a fictional story so that two different ways to celebrate this Catholic saint were available, which demonstrates a very contemporary approach: a sort of double coronation, one factual and one fictional, in which the real figure was substituted by the fictional character, almost more authentic than the original one.

Religious fictions have been a real success for the Italian television - for both the private and public channels - in particular since 2000, the Jubilee year. It is a phenomenon (in view of its impact on the public and its role in building a collective memory of modern society $)^{50}$ which has emerged recently, and which underlines this singularly superficial way of describing the religious dimension. Numerous biopics on Saints, such as Padre Pio, Saint Francis, Saint Anthony, on Lourdes, Fatima and - naturally - the Popes have been aired, all with the characteristic mixture of sacred and profane elements, reaching a large audience (nevertheless, most of these fictions are based on hagiographical reconstructions). The television film on Pope John XXIII was the most watched fiction in 2003, very much like the one on Pope John Paul II, aired shortly after his death. Every great religious event is always accompanied by a TV fiction that thematizes the event itself. The accompanying

${ }^{49}$ M. Buonanno, Cerimonie televisive. La duplice incoronazione di Madre Teresa di Calcutta, [in:] M. Buonanno, L'età della televisione. Esperienze e teorie, Bari 2006.

${ }^{50}$ See for examples, the concept "television of memories" formulated by M. Scaglioni, L'immagine come fonte, evento e memoria, [in:] A. Grasso (ed.), Fare storia con la televisione, pp. 17-46. 
feature usually becomes more important than the event it represents by giving the televiewers the coordinates to read, to interpret and to remember it. The biography of Pius XII, for examples, is not the one written by the historians, but the one showed by the TV fiction (Sotto il cielo di Roma, directed by Christian Duguay, with James Cromwell, 2010). This is the reason why some scholars talk about the "television of memories": it is TV that tells people what and how to remember things.

\section{Federico Ruozzi \\ KOŚCIÓŁ KATOLICKI I WLOSKA TELEWIZJA PUBLICZNA. WIELOLETNIE ZWIĄZKI I SOBOROWE INTERLUDIUM}

\section{Streszczenie}

$\mathrm{W}$ ostatnich latach wszystkie religie zaczęły włączać się organizacyjnie w system medialny. Artykuł przedstawia powiązania Kościoła katolickiego z mediami, skupiając się na kwestii telewizyjnych transmisji obrad II Soboru Watykańskiego. Autor przedstawia tło i historię Soboru, a także dzieli się spostrzeżeniami na temat polityki relacjonowania wydarzeń soborowych we włoskiej telewizji publicznej. Jego zdaniem, skupienie uwagi środków masowego przekazu na soborze miało dwojaki wymiar: choć media przekazywały więcej informacji o Kościele niż kiedykolwiek przedtem, jednocześnie wywierały wpływ na debaty ojców soborowych. Artykuł wieńczą uwagi na temat obrazu Kościoła katolickiego we współczesnej telewizji włoskiej.

\section{Bibliography}

Alberigo G., Papa Giovanni (1881-1963), Bologna 2000.

Alberigo G., Komonchak J.A. (eds. for the English ed.), 1-5, History of Vatican II, Maryknoll-Leuven 1995-2006.

Ambrosio G., La Chiesa e i media, Milano 1996.

Baragli E., Inter Mirifica, Roma 1969.

Bignell J., Fickers A. (eds.), A European Television History, New York 2009.

Boni F., Il corpo mediale del leader, Roma 2002.

Buonanno M., L'età della televisione. Esperienze e teorie, Roma-Bari 2006.

Câmara H., Vaticano II: Correspondêcia conciliar. Circulares á família do São Joaquim, L.C. Marques (ed.), Obras completas: 1/1, 1962-1964, Istituto dom Helder Câmara, Recife 2004. 
Campbell H.A. (ed.), Digital religion: Understanding religious practice in new media worlds, Abingdon-New York 2013.

Ceccuti C., Il concilio Vaticano I nella stampa italiana (1869-1870), Roma 1970.

Congar Y., Mon Journal du Concile, I-II, É. Mathieu (ed.), Paris 2002.

Chenu M.-D., Notes quotidiennes au Concile, A. Melloni (ed.), Paris 1995.

Dayan D., Katz E., Media Events. The Live broadcasting of History, Cambridge Mass. 1992.

Deacy C., Arweck E. (eds.), Exploring Religion and the sacred in a Media Age, Farnham 2009.

Delporte C., Gervereau L., Maréchal D. (eds.), Quelle est la place des images en histoire?, Paris 2008.

Echchaibi N., From audio tapes to video blogs: The delocalisation of authority, Islam, Nations and Nationalism 17, 1, 2011, pp. 25-44.

Eilers F.-J., Inter mirifica in Asia, Concilium 1, 2014, pp. 133-134.

Eugeni R., Viganò D.E. (eds.), Attraverso lo schermo. Cinema e cultura cattolica in Italia, 1-3, Roma 2006.

Faggioli M., Vatican II: The Battle for Meaning, New York 2012.

Fickers A., Johnson C. (eds.), Transnational Television History. A Comparative Approach, London-New York 2012.

Grasso A. (ed.), Fare storia con la televisione. L'immagine come fonte, come evento, come memoria, Milano 2006.

Hoover S.M., Religion in the Media Age, London-New York 2006.

Kochuthara S.G. (ed.), Revisiting Vatican II: 50 Years of Renewal, I, Keynote and Plenary Papers of the DVK International Conference on Vatican II, 31 January-3 February 2013, Bangalore 2014.

La Valle R., L'opinione pubblica e Giovanni XXIII: Essere giornalisti, Cristianesimo nella Storia 25, 2004, pp. 579-580.

Lercaro G., Lettere dal concilio 1962-1965, G. Battelli (ed.), Bologna 1980.

Mazza G. (ed.), Karol Wojtyła, un pontefice in diretta. Sfida e incanto nel rapporto tra Giovanni Paolo II e la tv, Roma 2006.

Melloni A. (ed.), Giuseppe Dossetti (1913-1996). Studies on an Italian Catholic Reformer. Bologna Lectures 2006, Münster 2008.

Melloni A., Papa Giovanni. Un cristiano e il suo concilio, Torino 2009.

Melloni A., Ruggieri G. (eds.), Chi ha paura del Vaticano II?, Roma 2009.

Meyer B., Moors A. (eds.), Religion, Media, and the Public Sphere, Bloomington 2006.

O'Malley J., Tradition and Transition. Historical perspectives on Vatican II, Wilmington 1988. 
O’Malley J., What happened at Vatican II, Cambridge, Mass. 2008.

Roberts G., Taylor P.M. (eds), The Historian, Television and Television History, Kent 2001.

Ruozzi F., Voci e immagini della fede: radio e tv, [in:] A. Melloni (ed.), Cristiani d'Italia 1861-2011. Chiese, società e Stato, Roma 2011, pp. 471-486.

Ruozzi F., Il concilio in diretta. Il Vaticano II e la televisione tra informazione e partecipazione, il Mulino, Bologna 2012.

Ruozzi F., India and Indian Catholicism on Italian television, [in:] S.G. Kochuthara (ed.), Revisiting Vatican II: 50 Years of Renewal, II, Selected Paper of the DVK International Conference on Vatican II, 31 January-3 February 2013, Bangalore 2015, pp. 179-199.

Scatena S. (ed.), 1962-2012: la storia dopo la Storia? Contributi e prospettive degli studi sul Vaticano II dieci anni dopo la Storia del concilio, Cristianesimo nella storia 31, 2013.

Schelkens K., The Council Notes of Edward Schillebeeckx 1962-1963, Leuven 2011.

Seib P., Janbek D.M., Global Terrorism and New Media, London-New York 2010.

Sorlin P., L'immagine e l'evento. L'uso storico delle fonti audiovisive, Torino 1999.

Tincq H., Le pape François est devenu le roi de la com' [online]. Slate France [access : 2014-03-12]. Available at: <http://www.slate.fr/story/84459/pape-francoiscommunication-twitter>.

Uva C., Il terrore corre sul video, Soveria Mannelli 2008.

Veuillot L., Rome pendant le concile, 1-2, Paris 1872.

Viganò D.E. (ed.), Telecamere su San Pietro. I trent'anni del Centro Televisivo Vaticano, Milano 2013.

Willebrands J., Les agendas conciliares de mgr J. Willebrands, L. Declerck (ed.), Leuven 2009. 